\title{
Pengaruh Zakat, Infak Sedekah, dan Inflasi Terhadap Kemiskinan di Indonesia
}

\author{
Muhammad Najib Murobbi \\ Universitas Indonesia \\ najibmurobbi@gmail.com \\ Hardius Usman \\ Politeknik Statistika STIS dan Universitas Indonesia \\ hardius@stis.ac.id
}

\begin{abstract}
Abstrak Kemiskinan merupakan salah satu permasalahan besar yang dialami di setiap negara. Berbagai bentuk kebijakan dan peraturan telah dilakukan dengan tujuan meminimalisir besarnya tingkat kemiskinan. Dari mulai bentuk makro dan mikro telah dilakukan. Namun dengan tingkat populasi dan permasalahan yang terus meningkat belum juga mampu mengatasi permasalahan kemiskinan. Dalam Islam terdapat beberapa berbagai instrumen yang mampu menjawab dan mengatasi permasalahan kemiskinan, yaitu berupa zakat, infak dan sedekah. Dengan tiga instrumen ini serta mengikutsertakan inflasi sebagai variabel lainnya akan dilihat pengaruhnya dengan kemiskinan yang ada di Indonesia. Oleh karena itu penelitian ini bertujuan untuk menguji pengaruh zakat, infak sedekah, dan inflasi terhadap kemiskinan di Indonesia tahun 2001 - 2018. Penelitian ini mengacu pada penelitian deskriptif kuantitatif dengan uji regresi berganda. Data yang digunakan adalah time series data, rentang waktu penelitian ini antara 2001 -2018. Sumber data diperoleh dari BAZNAS (Badan Amil Zakat Nasional), BPS (Badan Pusat Statistik), dan BI (Bank Indonesia). Hasil penelitian menunjukkan bahwa penerimaan zakat berpengaruh signifikan dalam menurunkan jumlah penduduk miskin. Sedangkan infak sedekah dan inflasi tidak memiliki hubungan yang signifikan terhadap kemiskinan dan memiliki hubungan negatif. Hal ini dibuktikan dengan nilai variabel zakat lebih kecil dari 0,05 yaitu 0,0042. Sedangkan variabel infak sedekah dan inflasi lebih besar dari 0,05, yaitu 0,7564 dan 0,7520.
\end{abstract}

\section{Kata Kunci Zakat, Infak Sedekah, Inflasi, Kemiskinan}

\section{PENDAHULUAN}

Kemiskinan merupakan suatu standar tingkat hidup yang rendah, yaitu adanya suatu tingkat kekurangan materi pada sejumlah atau segolongan orang dibandingkan dengan standar kehidupan yang umum berlaku dalam masyarakat yang bersangkutan (Suparlan, 1993). Kemiskinan juga merupakan masalah global yang dihadapi dan menjadi perhatian orang di dunia. Negara miskin masih dihadapkan antara masalah pertumbuhan dan distribusi pendapatan yang tidak merata. Sementara itu banyak negara berkembang yang mengalami pertumbuhan ekonomi namun kurang memberikan manfaat bagi penduduk miskinnya (Todaro \& Smith, 2006). Indonesia merupakan negara sebagian berkembang 
yang ada di dunia, umumnya negara berkembang adalah negara yang belum mencapai tingkat industrialisasi yang relatif terhadap penduduknya dan memiliki standar hidup menengah ke rendah.

Salah satu permasalahan yang dialami Indonesia dari masa ke masa adalah kemiskinan. Menurut Badan Pusat Statistik (BPS) kemiskinan dipandang sebagai ketidak mampuan dari sisi ekonomi untuk memenuhi kebutuhan makanan maupun non makanan yang bersifat mendasar. Word Bank mendefinisikan kemiskinan sebagai hilangnya kesejahteraan (deprivation of well being). Lebih sederhananya adalah seseorang yang dikatakan sebagai penduduk miskin adalah mereka yang berpenghasilan kurang $\$ 5$ per hari.

Tingkat kesejahteraan dapat diartikan sebagai kemampuan untuk mengakses sumber daya yang tersedia (barang yang dikonsumsi). Kemampuan akses sumber daya yang tersedia ini dapat diukur melalui jumlah pendapatan ataupun pengeluaran. Adapun beberapa penyebab kemiskinan antara lain:

1. Secara makro, kemiskinan mucul karena adanya ketidaksamaan pola kepemilikan sumber daya yang menimbulkan distribusi pendapatan timpang, penduduk miskin hanya memiliki sumber daya dalam jumlah yang terbatas dan kualitasnya rendah.

2. Kemiskinan muncul akibat perbedaan kualitas sumber daya manusia karena kualitas sumber daya manusia yang rendah berarti produktivitas juga rendah, upahnya pun rendah.

3. Kemiskinan muncul sebab perbedaan akses dan modal (Kuncoro, 2003)

Dalam data BPS angka kemiskinan di Indonesia cukup terbilang besar, walaupun pertumbuhan ekonomi mengalami peningkatan, hal tersebut dapat dilihat pada tabel 1:

Tabel 1

Jumlah Penduduk Miskin di Indonesia

\begin{tabular}{|r|r|r|r|}
\hline Tahun & Jumlah Penduduk Miskin & Tahun & Penduduk Miskin \\
\hline 2001 & 37.870 .000 & 2010 & 31.020 .000 \\
\hline 2002 & 38.390 .000 & 2011 & 29.890 .000 \\
\hline 2003 & 37.340 .000 & 2012 & 28.590 .000 \\
\hline 2004 & 36.150 .000 & 2013 & 28.550 .000 \\
\hline 2005 & 35.100 .000 & 2014 & 28.280 .000 \\
\hline 2006 & 39.300 .000 & 2015 & 28.510 .000 \\
\hline 2007 & 37.170 .000 & 2016 & 27.730 .000 \\
\hline 2008 & 34.960 .000 & 2017 & 27.770 .000 \\
\hline 2009 & 32.530 .000 & 2018 & 25.950 .000 \\
\hline
\end{tabular}

Sumber: BPS

Tabel 1 menginformasikan bahwa Indonesia masih hidup di dalam lingkaran kemiskinan. Tingginya angka kemiskinan di Indonesia diakibatkan karena masyarakat tidak memperoleh modal, pendapatan, informasi, dan pendidikan dengan baik. Sehingga, masayarakat tidak mampu menyerap informasi dan teknologi yang semakin berkembang. 
Dalam Islam terdapat instrument yang mampu membantu mengatasi permasalahan kemiskinan, yaitu zakat. Islam menjadikan instrument zakat untuk memastikan keseimbangan pendapatan di masyarakat. Ini berarti, tidak semua orang mampu bergelut dalam kancah ekonomi, karena sebagian mereka ada yang tidak mampu baik fakir maupun miskin. Pengeluaran dari zakat adalah pengeluaran minimal untuk membuat distribusi pendapatan menjadi lebih merata. Dengan zakat, orang fakir dan miskin dapat berperan dalam kehidupannya, melaksanakan kewajiban kepada Allah. Dengan zakat, orang yang tidak berpunya juga merasa bahwa mereka merupakan bagian dari masyarakat. Orang miskin juga merasa dihargai karena ada empati dari orang yang berpunya (Atabik, 2015)

\section{LANDASAN TEORI}

Dalam bidang ekonomi, zakat bisa berperan dalam pencegahan terhadap penumpukan kekayaan pada segelintir orang saja dan mewajibkan orang kaya untuk mendistirbusikan harta kekayaannya kepada sekelompok orang fakir dan miskin. Maka, zakat juga berperan sebagai sumber dana yang potensial untuk mengatasi kemiskinan. Zakat juga bisa berfungsi sebagai modal kerja bagi orang miskin untuk dapat membuka lapangan pekerjaan, sehingga bisa berpenghasilan dan dapat memenuhi kebutuhan sehari-harinya (Rozalinda, 2014).

Zakat adalah jumlah harta tertentu yang wajib dikeluarkan oleh orang yang beragama Islam dan diberikan kepada golongan yang berhak menerimanya (fakir miskin dan mustahik lainnya) menurut ketentuan yang telah ditetapkan oleh syariat. Yusuf Qardhawi mengemukakan bahwa:

a. Zakat adalah bagian dari harta dengan persyaratan tertentu, yang Allah SWT mewajibkan kepada pemiliknya (muzakki), untuk diserahkan kepada yang berhak menerimanya (mustahiq) dengan persyaratan tertentu pula.

b. Zakat merupakan maaliyah ijtima 'iyah, artinya ibadah di bidang harta yang karena itudi dalam Al-Qur'an dan Hadist banyak perintah untuk berzakat, sekaligus pujian bagi yang melakukannya

Dalam penelitian terdahulu, Purwanti (2020) dengan judul Pengaruh Zakat, Infak, dan Sedekah Terhadap Pertumbuhan Ekonomi Indonesia berkesimpulan bahwa zakat indak dan sedekah (ZIS) yang berhasil dihimpun terbukti berpengaruh positif terhadap pertumbuhan ekonomi Indonesia. Hal ini dibuktikan dengan metide analisi yang digunakannya regresi panel dengan driscoll and kraay standars errors. Dari 34 provinsi selama periode 2013 sampai 2017 serta variabel PDRB dan ZIA yang berdasarkan sistem IT SIMBA menunjukkan adanya korelasi yang positif antar variabel. Dengan adanya pengaruh zakat, infak dan sedekah yang positif terhadap perekonomian Indonesia, maka hal ini juga berdampak pada meningkatnya konsumsi mustahik atau orang yang berhak menerima zakat dalam hal ini adalah masyarakat miskin.

Penelitian dari Tambunan, Harahap, \& Marliyah (2019) dengan judul penelitian Analisis Kointegrasi Zakat dan Pertumbuhan Ekonomi Indonesia Periode Tahun 2015-2018 berkesimpulan bahwa variabel zakat berpengaruh secara signifikan terhadap perekonomian dengan indikator PDB. Zakat berpengaruh terhadap perekonomian masyarakat baik secara jangka pendek maupun jangka panjang. Dan hasil dari uji 
kointegrasi zakat dan pertumbuhan ekonomi memiliki hubungan jangka panjang dan pendek.

Penelitian dari Andrini \& Ilmiawan (2019) dengan judul Pengaruh Variabel Makro Ekonomi dan Penyaluran Zakat, Infak, dan Sedekah Oleh Badan Amil Zakat Nasional Terhadap Kemiskinan Di Indonesia berkesimpulan bahwa variabel PDB, inflasi, rasio gini, dandistribusi ZIS dari BAZNAS memiliki pengaruh yang negatif dan signifikan terhadap kemiskinan di dalam jangka panjang. Pengangguran memiliki pengaruh yang positif dan signifikan terhadap kemiskinan di dalam jangka panjang. PDB, inflasi, dan distribusi ZIS berpengaruh negatif dan tidak signifikan secara statistik terhadap kemiskinan di dalam jangkapendek. Rasio gini berpengaruh negatif dan signifikan secara statistik terhadap kemiskinan. Sedangkan variabel pengangguran berpengaruh positif dan tidak signifikan secara statistik terhadap kemiskinan. PDB, pengangguran, inflasi, rasio gini, dan distribusi ZIS secara bersama-sama dapat memengaruhi kemiskinan di dalam jangka panjang dan jangka pendek.

Penelitian dari Ratnasari \& Firdayetti (2016) dengan judul penelitian Analisis Pengaruh Zakat, Infak, Sedekah, dan Usyr (Pajak Impor) Terhadap Kemiskinan Di Indonesia berkesimpulan bahwa dana zakat mempunyai pengaruh signifikan dengan hubungan negatif terhadap penurunan kemiskinan di Indonesia periode 2001-2016. Sedangkan infak dan sedekah tidak mempunyai pengaruh yang signifikan dengan hubungan positif terhadap penuruankemiskinan di Indonesia periode 2001-2016. Dan usyr (pajak impor) memiliki pengaruh yangsignifikan terhadap kemiskinan dengan hubungan yang positif.

Penelitian dari Meiliana (2019) dengan judul Analisis Pengaruh UPM dan Distribusi Dana Zakat, Infaq, Shadaqah Terhadap Jumlah Kemiskinan Di 21 Provinsi Indonesia Tahun 2014-2017 berkesimpulan bahwa UMP berpengaruh positif dan signifikan. Distribusi dana ZIS berpengaruh negatif signifikan dan variabel UMP dana distribusi dana ZIS secara bersama sama berpengaruh signifikan terhadap jumlah kemiskinan di 21 provinsi Indonesia tahun 2014- 2017. Jadi, dari beberapa penelitian tersebut bisa disimpulkan bahwa inflasi, zakat, infak dan shadaqah mampu menjadi sebuah solusi untuk meningkatkan pertumbuhan ekonomi dan menurunkan angka kemiskinan.

\section{III. METODOLOGI PENELITIAN}

Penelitian ini mengacu pada penelitian deskriptif kuantitatif yaitu data yang diperoleh dan dianalisis sesuai dengan metode statistik kemudian diinterpretasikan. Penelitian deskriptif kuantitatif dengan uji regresi berganda. Tujuan dari pengujian analisis regresi berganda adalah untuk melihat pengaruh yang terjadi antar variabel independen (Inflasi, Zakat, Infak dan Sedekah) terhadap variabel dependen (Kemiskinan). Data yang digunakan adalah time series data, rentang waktu penelitian ini antara 2001-2018. Data yang diperoleh dalam penelitian ini bersumber dari BAZNAS (Badan Zakat Nasional), BPS (Badan Pusat Statiatik), dan BI (Bank Indonesia).

Tabel 2. Variabel Independen

\begin{tabular}{|r|r|r|r|}
\hline TAHUN & \multicolumn{1}{|c|}{ Zakat (X1) } & \multicolumn{1}{|c|}{ Infak (X2) } & \multicolumn{1}{|c|}{ Inflasi (X3) } \\
\hline 2001 & $120.694 .549,04$ & $34.087 .961,29$ & 12,55 \\
\hline 2002 & $288.692 .612,00$ & $241.844 .931,33$ & 10,03 \\
\hline 2003 & $1.307 .300 .388,00$ & $483.372 .351,00$ & 5,06 \\
\hline
\end{tabular}




\begin{tabular}{|r|r|r|r|}
2004 & $2.224 .208 .964,64$ & $598.055 .649,00$ & 6,4 \\
\hline 2005 & 2.540 .588 .847 & 28.784 .807 .942 & 17,11 \\
\hline 2006 & 4.825 .501 .587 & 12.455 .537 .060 & 6,6 \\
\hline 2007 & 8.307 .940 .585 & 6.017 .072 .950 & 6,59 \\
\hline 2008 & 15.355 .092 .415 & 3.288 .376 .976 & 11,06 \\
\hline 2009 & 19.371 .179 .661 & 5.887 .760 .394 & 2,78 \\
\hline 2010 & 23.661 .022 .281 & 3.483 .270 .163 & 6,96 \\
\hline 2011 & 32.986 .949 .797 & 7.278 .931 .449 & 3,79 \\
\hline 2012 & 40.387 .972 .149 & 9.824 .463 .726 & 4,3 \\
\hline 2013 & 50.741 .735 .215 & 6.762 .818 .800 & 8,38 \\
\hline 2014 & 69.865 .506 .671 & 12.399 .311 .420 & 8,36 \\
\hline 2015 & 82.272 .643 .293 & 11.796 .250 .526 & 3,35 \\
\hline 2016 & 97.637 .657 .910 & 14.053 .256 .518 & 3,02 \\
\hline 2017 & 138.096 .290 .551 & 16.032 .383 .602 & 3,61 \\
\hline 2018 & 153.153 .229 .174 & 41.938 .822 .768 & 3,13 \\
\hline
\end{tabular}

\section{METODE ANALISIS DATA TIME SERIES}

\section{a. Time Series}

Metode time series adalah metode peramalan dengan menggunakan analisa pola hubungan antara variabel yang akan dipekirakan dengan variabel waktu. Peramalan suatu datatime series perlu memperhatikan tipe atau pola data. Secara umum terdapat empat macam poladata time series, yaitu horizontal, trend, musiman, dan siklis. Pola horizontal merupakan kejadian yang tidak terduga dan bersifat acak, tetapi kemunculannya dapat memepengaruhi fluktuasi data time series. Pola trend merupakan kecenderungan arah data dalam jangka panjang, dapat berupa kenaikan maupun penurunan. Pola musiman merupakan fluktuasi dari data yang terjadi secara periodik dalam kurun waktu satu tahun, seperti triwulan, kuartalan, bulanan, mingguan, atau harian. Sedangkan pola siklis merupakan fluktuasi dari data untuk waktu yang lebih dari satu tahun (Hanke \& Wichern, 2005).

\section{b. Stasioneritas}

Stasioneritas berarti bahwa tidak terjadinya pertumbuhan dan penurunan data. Suatu data dapat dikatakan stasioner apabila pola data tersebut berada pada kesetimbangan disekitar nilai rata-rata yang konstan dan variansi disekitar rata-rata tersebut konstan selama waktu tertentu. Time series dikatakan stasioner apabila tidak ada unsur trend dalam data dan tidak adaunsur musiman atau rata-rata dan variannya tetap, seperti pada Gambar 1.1

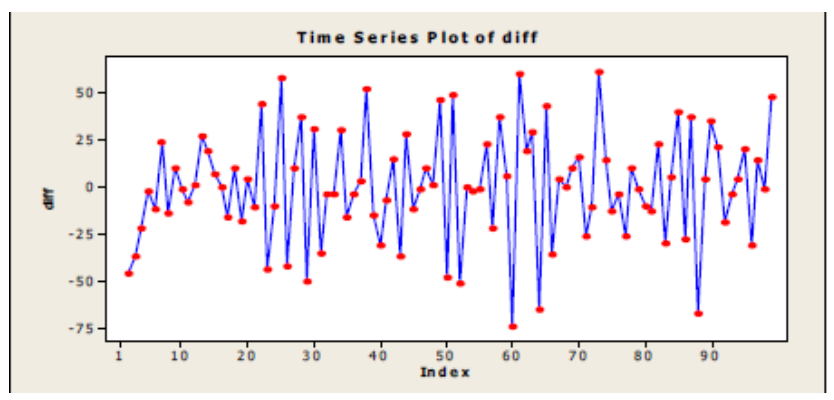

Gambar 1.1 Plot time series data statisioner dalam rata-rata dan variansi (Hanke, 2005) 
Penelitian ini menggunakan analisi model time series dengan rentan waktu tahunan. Mula 2001-2018 yang diambil dari Badan Amil Zakat Nasional (BAZNAS) Badan Pusat Statistik (BPS), dan Bank Indonesia (BI). Adapaun bentuk modelnya sebagai berikut:

Time Series:

$Y_{i}=\beta 0+\beta 1 X_{1} t+\beta 2 X_{2} t+\beta 3 X_{3 t}+\beta k X_{k t}+u t$

$\mathrm{t}=1,2,3$, .. T

Dimana:

$\mathrm{Y}$ adalah data time series yang akan diperkirakan

$t$ adalah variabel waktu

$X 1$ adalah Zakat

$X 2$ adalah Infak/Sedekah

$X 3$ adalah Inflasi

Definisi operasional yang digunakan dalam penelitian ini adalah sebagai berikut:

1. Kemiskinan pada tahun 2001 sampai 2018 yang diambil menurut Badan Pusat Statistik (BPS) secara umum mengalami fluktuatif dengan rata-rata mengalami penurunan. Penuruan tersebut tidak lepas dari upaya keras pemerintah dalam menaggulangi kemiskinan dengan berbagai program yang ditawarkan, walaupun belum bisa dikatakan maksimal.

2. Inflasi pada sepuluh tahun terakhir terbilang rendah. Data yang diambil pada penelitian ini adalah inflasi dari tahun 2001 sampai 2018. Dalam data Bank Indonesia (BI) menunjukkan bahwa inflasi terendah pada tahun 2018 sebesar 3,13\%. Walaupun pada tahun 2009 menjadi angka inflasi terendah 2,785\% dan 3,02\% pada tahun 20176.

3. ZIZ yang dihimpun merupakan jumlah penerimaan dana zakat dan infak sedekah yang berhasil dihimpun oleh BAZNAZ dari perorangan maupun lembaga atau kelompok (dalam miliar rupiah)

\section{HASIL PENELITIAN}

Secara umum angka kemiskinan di Indonesia sejak 2001 - 2018 mengalami fluktuatif dengan rata-rata mengalami penurunan. Hal ini tidak lepas dari upaya pemerintah dengan kebijakan dan regulasi yang diberikan kepada lapisan masyarakat dengan ekonomi menengah ke bawah. Walaupun belum maksimal, akan tetapi tren penurunan menunjuan

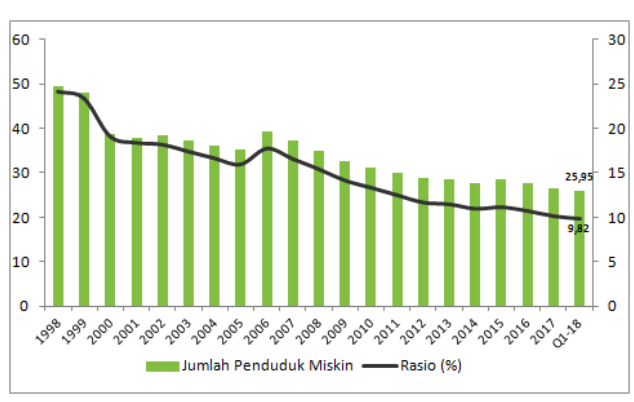

Gambar 2.1 Kemiskinan di Indonesia 1998 - 2018 bahwa program-program penanggulangan kemiskinan terus diluncurkan oleh pemerintah. Berdasarkan gambar 2 pada tahun 2001-2005 jumlah penduduk miskin relatif mengalami penurunan dari 37,87 juta jiwa. Namun pada tahun 2006 terjadi kenaikan jumlah penduduk miskin yang relatif besar, dari 35,10 juta jiwa pada tahun 2005 menjadi 39,30 juta jiwa.

Faktor terbesar karena pada tahun tersebut terjadi kenaika harga BBMyang menyebabkan naiknya harga barang. Akibatnya penduduk dengan ekonomi mengengah ke bawah menjadi terus bertambah. Menurut Siregar \& Wahyuni (2008) menjelaskan bahwa seseorang dikatakan miskin atau hidup dalam masalah 
kemiskinan jika pendapatan atau aksesnya terhadap barang dan jasa relatif rendah dibandingkan rata-rata orang lain dalam perekonomian tersebut. Secara absolut, seseorang dinyatakan miskin apabila tingkat pendapatan atau standar hidupnya secara absolut berada dibawah subsisten. Ukuran subsistensitersebut dapat diproduksi dengan garis kemiskinan.Menurut bank dunia ada tiga faktor penyebab kemiskinan yaitu:

1. Rendahnya pendapatan dan aset untuk memenuhi kebutuhan dasar seperti makanan, tempat tinggal, pakaian, kesehatan dan pendidikan.

2. Ketidak mampuan bersuara dan ketiadaan kekuatan didepan institusi negara dan masyarakat.

3. Rentan terhadap guncangan ekonomi terkait dengan ketidak mampuan menanggulanginya. Untuk mengukur kemiskinan, Indonesia melalui BPS menggunakan pendekatan kebutuhan dasar (basic needs) yang dapat diukur dengan angka atau hitungan Indeks

Tabel 2. Hasil Estimasi Persamaan Regresi Kemiskinan

\begin{tabular}{lrrrr} 
Variable & Coefficient & Std. Error & \multicolumn{2}{c}{ t-Statistic Prob. } \\
\hline \hline C & 35014885 & 1926965. & 18.17100 & 0.0000 \\
ZAKAT_X1_- & $-7.93 E-05$ & $2.33 E-05$ & -3.409126 & 0.0042 \\
INFAK_X2_- & $2.82 E-05$ & $8.92 E-05$ & 0.316379 & 0.7564 \\
INFLASI_X3_- & 70240.24 & 217979.5 & 0.322233 & 0.7520
\end{tabular}

\begin{tabular}{lcll} 
R-squared & 0.713525 & Mean dependent var & 32505556 \\
Adjusted R-squared & 0.652137 & S.D. dependent var & 4490433. \\
S.E. of regression & 2648452. & Akaike info criterion & 32.60998 \\
Sum squared resid & $9.82 \mathrm{E}+13$ & Schwarz criterion & 32.80784 \\
Log likelihood & -289.4898 & Hannan-Quinn criter. & 32.63726 \\
F-statistic & 11.62329 & Durbin-Watson stat & 0.688529 \\
Prob(F-statistic) & 0.000431 & \\
\hline
\end{tabular}

\section{Data diolah Eviews 10}

Dalam pengujian ini menunjukan bahwa pengujian terhadap variabel zakat berpengaruh signifikan dengan hubungan yang negatif terhadap kemiskinan, dimana pengaruhzakat terhadap kemiskinan sebesar -7.93E-05, artinya apabila penerimaan zakat sebesar 1 miliyar rupiah maka proporsi penduduk miskin akan turun sebesar 7.9300 orang. Hal ini sesuai dengan hipotesa, semakin tunggi dana zakat yang diterima maka tingkat kemiskinan diIndonesia akan turun.

Tabel 3. Hasil Estimasi

\begin{tabular}{|l|l|l|l|l|l|}
\hline & Variable & Coefficient & Std. Error & t-Statistic & Prob. \\
\hline C & 35014885 & 1926965. & 18.17100 & $\begin{array}{l}0.000 \\
0\end{array}$ \\
\hline & ZAKAT_X1 & $-7.93 E-05$ & $2.33 E-05$ & $\begin{array}{l}- \\
3.409126\end{array}$ & $\begin{array}{l}0.004 \\
2\end{array}$ \\
\hline & INFAK_X2_ & $2.82 \mathrm{E}-05$ & $8.92 \mathrm{E}-05$ & 0.316379 & $\begin{array}{l}0.756 \\
4\end{array}$ \\
\hline & INFLASI_X3 & 70240.24 & 217979.5 & 0.322233 & $\begin{array}{l}0.752 \\
0\end{array}$ \\
\hline
\end{tabular}


Hasil dari penelitian ini sama dengan penelitian dari (Ratnasari \& Firdayetti, 2016) dengan judul penelitian Analisis Pengaruh Zakat, Infak, Sedekah, dan Usyr (Pajak Impor) Terhadap Kemiskinan Di Indonesia yang manyatakan bahwa zakat mampu mengurangi jumlahdan presentase keluarga miskin yang sesuai dengan teori.

Berdasarkan hasil regresi liner berganda bisa dilihat bahwa penerimaan zakat berpengaruh signifikan dalam menurunkan jumlah penduduk miskin. Jadi, pada variabel Zakatmempengaruhi secara signifikan terhadap variabel kemiskinan. Hal ini dibuktikan dengan nilaivariabel zakat lebih kecil dari 0,05, yaitu 0,0042. Salah satu faktor yang mendukung adalah kesadaran masyarakat dalam menunaikan kewajiban membayar zakat dan pengelolaan zakat yang profesional dan sesuai dengan prosedur.

Pengentasan kemiskinan menjadi salah satu dari peran zakat dalam pembangunan, setidaknya ada 4 (empat) peran zakat, antara lain : (1) memoderasi kesenjangan sosial; (2) membangkitkan ekonomi kerakyatan; (3) mendorong munculnya model terobosan dalam pengentasan kemiskinan; dan (4) mengembangkan sumber pendanaan pembangunan kesejahteraan umat di luar APBN maupun APBD. Pertama, peran moderasi kesenjangan sosial yang dapat dilakukan oleh zakat tampak secara konkret dalam distribusi harta dari para wajib zakat (muzakki)kepada orang yang berhak menerima zakat (mustahik), dengan amil zakat sebagai perantara. Redistribusi ini akan mengurangi kesenjangan sosial. Kedua, Penyaluran zakat kepada mustahik memiliki agenda untuk meningkatkan kemampuan mereka dalam mencukupi kebutuhan hidupnya, baik yang dalam bentuk pendistribusian zakat. Ketiga, zakat memiliki peran dalam mendorong munculnya model terobosan dalam pengentasan kemiskinan. Program penanggulangan kemiskinan yang ada selama ini merupakan program belas kasih daripemerintah kepada orang-orang miskin. Keempat, zakat merupakan sumber pendanaan pembangunan kesejahteraan umat di luar APBN maupun APBD. Jika selama ini program penanggulangan kemiskinan sangat bergantung pada kucuran dana pemerintah, maka sejatinya, umat Islam di Indonesia memiliki potensi dana Rp 286 triliun setiap tahunnya yang dapat dipergunakan secara spesifik bagi kelompok orang yang tidak berdaya dalam delapan ashnaf (kategori) mustahik. Jika dapat dioptimalkan, maka potensi dana zakat ini dapat menjadipelengkap agenda program penanggulangan kemiskinan dengan sinergi pada program pemerintah yang sedang dijalankan.

Hasil pengujian menunjukan bahwa variabel infak dan sedekah tidak memiliki pengaruh yang signifikan terhadap kemiskinan dan memiliki hubungan yang negatif artinya apabila infak dan sedekah meningkat maka kemiskinan akan menurun. Hal ini tidak sesuai dengan hipotesa yang seharusnya infak dan sedekah memiliki pengaruh yang signifikan terhadap kemiskinan dengan hubungan yang negatif. Hasil pengujian dalam penelitian ini samadengan hasil analisa (Ratnasari \& Firdayetti, 2016) yang menunjukan bahwa variabel infak sedekah tidak memiliki pengaruh negatif dan signifikan terhadap kemiskinan yang tidak sesuaidengan hipotesa dalam jurnal Faktor Sosial Ekonomi Yang Mempengaruhi Penurunan Kemiskinan Di Indonesia Dalam Perspektik Islam.

Berdasarkan hasil regresi tersebut bisa dilihat bahwa penerimaan infak dan sedekah tidak memiliki pengaruh signifikan dalam menurunkan jumlah penduduk miskin. Variabel Infak tidak mempengaruhi signifikan terhadap variabel kemiskinan. Hal ini dibuktikan dengan nilai variabel infak lebih besar dari 0,05, yaitu 0,7564. Dan hal tersebut 
dikarenakan masyarakat pada umumnya lebih memilih untuk memberikan secara langsung tanpa lembaga BAZNAS. Hal ini menyebabkan data yang terkumpul menjadi kecil nilainnya sehingga dana infak dan sedekah tidak memiliki pengaruh terhadap kemiskinan. Pada BAZNAS dana infak dan sedekah dialokasikan ke sektor konsumtif seperti sandang dan obat-obatan sehingga tidak memiliki dampak yang signifikan terhadap penurunan kemiskinan

Hasil pengujian juga menunjukan bahwa variabel inflasi tidak memiliki pengaruh yang signifikan terhadap kemiskinan. Hal ini dubuktikan dengan nilai variabel inflasi lebih besar dari 0,05 , yaitu 0,7520 . Variabel inflasi tidak berpengaruh signifkan dan positif terhadap pertumbuhan ekonomi di Indonesia. Jika inflasi meningkat maka kemiskinan akan meningkat. Sebaliknya, jika inflasi menurun, maka angka kemiskinan akan berkurang. Hasil ini juga didukung oleh teori yang menyatakan bahwa inflasi akan menigkatkan biaya produksi yang menimbulkan kenaikan harga barang dan jasa. Kenaikan harga ini menyebabkan daya beli masyarakat menurun dan berujung pada peningkatan kemiskinan. Dan nilai Adjusted R- squared pada penelitian ini sebesar 0.652137, artinya 65\% variabel Zakat, Infak, dan Inflasi mempengaruhi kemiskinan dan sisanya dipengaruhi di luar penelitian

\section{KESIMPULAN}

Berdasarkan hasil penelitian ini dapat diperoleh simpulan bahwa pada variabel penerima dana zakat dalam penelitian ini mempunyai pengaruh yang signifikan dengan hubungan yang negatif terhadap penurunan kemiskinan di Indonesia periode 2001-2018, sesuai dengan hipotesa yaitu zakat mempunyai pengaruh signifikan dengan hubungan yang negatif terhadap penurunan kemiskinan. Hal tersebut dikarenakan adanya semangat berbagai melalui zakat dan pengelolaan dana zakat yang baik. Pada variabel penerima dana infak dan sedekah dalam penelitian ini tidak mempunyai pengaruh yang signifikan dengan hubungan yang positif terhadap penurunan kemiskinan di Indonesia periode 2001-2018, tidak sesuai dengan hipotesa yaitu infak dan sedekah mempunyai pengaruh signifikan dengan hubungan yang negatif terhadap penurunan kemiskinan. Hal tersebut dikarenakan masyarakat pada umumnya lebih memilih untuk memberikan secara langsung tanpa lembaga BAZNAS. Hasil pengujian menunjukan bahwa pengujian terhadap variabel inflasi tidak memiliki pengaruh yang signifikan terhadap kemiskinan dengan hubungan yang positif, tidak sesuai dengan hipotesa yaitu inflasi memiliki pengaruh yang signifikan terhadap kemiskinan dengan hubungan yang negatif. Hal tersebut dikarenakan tingkat inflasi yang cenderung besar, sehingga harga barang pokok meningkat dan berdampak pada tingat kemiskinan.

\section{SARAN}

Dalam penelitian ini data zakat, infak dan sedekah hanya bersumber dari satu lembaga amil zakat, yaitu Baznas yang belum dapat mewakili dampak zakat terhadap kemiskinan. Diharapkan untuk penelitian selanjutnya data zakat, infak dan sedekah bisa diperoleh dari berbagai amil zakat agar diperoleh data yang lebih akurat. Dalam penelitian ini hanya meneliti dari tahun 2001-2018, diharapkan untuk penelitian selanjutnya untuk menambahkan periode atau dapat juga menggunakan data panel sehingga dapat mewakili dampak zakat, infak dan sedekah terhadap kemiskinan. Untuk penelitian selanjutnya menggunakan data primer dan sekunder sangat dianjurnak dengan tujuan penelitian yang 
diperoleh lebih akurat dan baik. Penambahan variabel diperlukan untuk melihat dampak zakat secara keseluruhan dan tidak hanya melihat dari variabel zakat, infak dan sedekah.

\section{DAFTAR PUSTAKA}

Andrini, J. F., \& Ilmiawan, A. (2019). Pengaruh Variabel Makro Ekonomi dan Penyaluran Zakat, Infak, dan Sedekah Oleh Badan Amil Zakat Nasional Terhadap Kemiskinan DiIndonesia. Jurnal Ekonomi Syariah Teori dan Terapan Vol. 6 No. 7 Juli, 1476-1493

Atabik, A. (2015). PERANAN ZAKAT DALAM PENGENTASAN KEMISKINAN. ZISWAF, Vol. 2, No. 2, Desember, 339-361.

Hanke, J. E. (2005). Business Forecasting John E Wichern Hanke. New Jersey: Pearson Prentice hall.

Kuncoro, M. (2003). Metode Riset untuk Bisnis dan Ekonomi. Jakarta: Erlangga.

Meiliana, D. (2019). Analisis Pengaruh UPM dan Distribusi Dana Zakat, Infaq, Shadaqah Terhadap Jumlah Kemiskinan Di 21 Provinsi Indonesia Tahun 2014-2017.

Purwanti, D. (2020). Pengaruh Zakat, Infak, dan Sedekah terhadap Pertumbuhan Ekonomi Indonesia. Jurnal Ilmiah Ekonomi Islam, 6(01), 101-107

Qardhawi, Y. (1996). Hukum Zakat Studi Kontemporer Mengenai Status dan Filsafat Zakat Berdasarkan Qur'an dan Hadi (Ter. Salman Harun dkk). Jakarta: Pustaka Mizani

Ratnasari, E., \& Firdayetti. (2016). Analisis Pengaruh Zakat, Infak, Sedekah, dan Usyr (PajakImpor) Terhadap Kemiskinan Di Indonesia. Media Ekonomi Vol. 26 No. 1 April, 39- 46

Rozalinda. (2014). Ekonomi Islam: Teori dan Aplikasinya pada Aktivitas Ekonomi. Jakarta: Rajagrafindo.

Siregar, H., \& Wahyuni, D. (2008). Dampak Pertumbuhan Ekonomi Terhadap Penurunan Jumlah Penduduk Miskin. http://pse.litbang.deptan.go.id/ind/pdffiles/PROS_2008_MAK3.pdf.

Suparlan, P. (1993). Kemiskinan di Perkotaan. Jakarta: Yayasan Obor Indonesia.

Tambunan, K., Harahap, I., \& Marliyah. (2019). Analisis Kointegrasi Zakat dan PertumbuhanEkonomi Indonesia Periode Tahun 2015-2018. AKTSAR Volume 2 Nomor 2, Desember,249-264

Todaro, M. P., \& Smith, S. (2006). Economic Development. New York: AddisonWesley. 